\title{
Formaldehyde-treated proteins for dairy cows - effects on blood hormone concentrations
}

\author{
By J. D. OLDHAM, I. C. HART AND J. A. BINES \\ National Institute for Research in Dairying, Shinfield, Reading, Berkshire RG2 9AT
}

(Received 23 November 1981-Accepted 4 June 1982)

1. Seven Friesian heifers in mid-lactation were used in an experiment to measure the effects of including casein, formaldehyde-treated casein or formaldehyde-treated soya-bean meal in the diet on performance and on the concentrations of certain metabolites and hormones in the blood.

2. Milk yield and the concentration of fat, protein and lactose in milk were not affected by the treatments.

3. The concentration of growth hormone $(\mathrm{GH})$ in jugular venous blood was higher with both formaldehydetreated proteins than it was with untreated casein $(P<0.05)$. Diet had no effect on insulin, prolactin or thyroxine concentrations in blood.

4. Urea concentration tended to be higher and non-esterified fatty acids lower in blood from heifers offered the diet containing untreated casein, but these differences were not statistically significant. Blood glucose concentration was not affected by dietary treatment.

5 . It was concluded that blood GH concentration can be increased by offering protein supplements which will increase total amino acid supply to the intestines in lactating cattle. This appears to be a direct effect on GH status independent of effects on milk yield.

Yields of milk and of milk protein can be raised by increasing amino acid supply to the intestines in dairy cows. When this has been done by abomasal infusion of casein the magnitude of response has been about $8 \%$ in milk yield and about $14 \%$ in milk-protein yield (Oldham, 1981). Similar responses have been found when the protein content of the diet has been increased (Roffler et al. 1978; Wohlt \& Clark, 1978; Gordon, 1979; Oldham et al. 1979; Ørskov et al. 1981; Phipps et al. 1981).

We have previously reported that increasing amino acid supply to the intestine, by abomasal infusion of casein, results in increased concentrations of growth hormone (GH) in blood of lactating goats (Oldham et al. 1978). In view of the known effects of changing GH status on milk yield (Bines \& Hart, 1982) this might suggest that part of the response in milk output to increased amino acid supply to the intestine is mediated via changes in GH status.

The aim of the experiment reported here was to see if increasing the supply of amino acids to the intestines was accompanied by increases in both the circulating concentrations of $\mathrm{GH}$ and milk yield in dairy cattle. Casein with or without formaldehyde-treatment ('protected' casein), and formaldehyde-treated soya-bean meal ('protected' soya-bean meal) were used as dietary ingredients designed to vary the supply of amino acids to the intestines.

\section{METHODS}

Animals and management. Seven Friesian heifers were housed in individual stalls. At the start of the e.zperiment they were in the 25-28th week post-partum. Food was offered twice daily, at 06.00 hours and 14.00 hours, and the heifers were milked shortly after each feed. Refused food was removed from the feed trough before the 14.00 hours feeding, and weighed.

Diets and experimental design. Details of the composition of the three experimental concentrates are given in Table 1 . These concentrates were prepared as loose mixtures and were offered with hay in the ratio 40:60 (w/w) hay: concentrates. In the first week of the 
Table 1. Composition of the experimental concentrates and intakes of dry matter (DM) and nitrogen $(N)$ by heifers offered diets containing casein, formaldehyde-treated casein (protected casein) or formaldehyde-treated soya-bean meal (protected soya)

\begin{tabular}{|c|c|c|c|c|}
\hline Diet... & Casein & $\begin{array}{l}\text { Protected } \\
\text { casein }\end{array}$ & $\begin{array}{l}\text { Protected } \\
\text { soya }\end{array}$ & $\begin{array}{c}\text { SE of } \\
\text { difference }\end{array}$ \\
\hline \multicolumn{5}{|l|}{ Ingredient $(\mathrm{g} / \mathrm{kg})$} \\
\hline Rolled barley & 484 & 484 & 370 & - \\
\hline Flaked maize & 320 & 320 & 320 & - \\
\hline Molassine meal & 100 & 100 & 100 & - \\
\hline Casein & 90 & $\ldots$ & - & - \\
\hline Protected casein ${ }^{*}$ & - & 90 & - & - \\
\hline Protected soya* & - & - & 200 & - \\
\hline Urea & 6 & 6 & 10 & - \\
\hline Supplements & 1 & 1 & 1 & - \\
\hline DM intake ( $\mathrm{kg} /$ day) & $11 \cdot 12$ & $10 \cdot 33$ & $11 \cdot 14$ & 0.391 \\
\hline $\mathrm{N}$ intake (g/day) & $272 \cdot 0^{\mathrm{b}}$ & $251 \cdot 1^{c}$ & $299 \cdot 4^{\mathrm{a}}$ & $7 \cdot 19$ \\
\hline
\end{tabular}

a, b, c. Mean which do not share a common superscript differ significantly $(P<0.05)$.

* Formaldehyde was added in the ratio ( $\mathrm{g}: \mathrm{g}) 1: 1$ to protein in solution (casein) or suspension (soya). The final product was spray-dried.

experiment, the level of feeding for each heifer was adjusted to minimize refusals of food. The level of feeding was held constant thereafter.

The heifers were divided into two groups, one of three and one of four. Each group was offered the treatments according to a $3 \times 3$ Latin square experimental design (modified for an extra heifer in the group of four). Treatment periods lasted 3 weeks. Treatments were changed abruptly at the end of each period.

Measurements. Milk yields and food intakes were recorded daily. In the first 2 weeks of each period, samples of milk were taken at four consecutive milkings and bulked according to yield. In the last week of the period bulk milk samples were taken for two consecutive 48-h periods.

On the penultimate day of each period, each heifer was fitted with an inc welling catheter (Portex Ltd, Hythe, Kent) in one jugular vein. On the last day, twenty-four blood samples were collected, at hourly intervals, and centrifuged. Blood plasma was separated and stored frozen $\left(-20^{\circ}\right)$ pending analysis.

Analysis. The dry matter (DM) and nitrogen content of foods was measured by standard procedures.

Milk samples were analysed for fat, protein and lactose concentration on an infra-red analyser (IRMA Mark II, Grubb Parsons, Newcastle upon Tyne).

Blood plasma was assayed for glucose, non-esterified fatty acids (NEFA), insulin, GH, prolactin and thyroxine concentration using the methods described by Hart et al. (1978). The concentration of urea in blood was measured using an automated procedure (Technicon Instruments Co, Ltd method no. N-1C) based on the method of Marsh et al. (1965).

Statistical analysis. Values were analysed using a replicated Latin square design experiment adjusted for an extra animal in one square.

\section{RESULTS}

Food intake. Intakes of DM and $\mathrm{N}$ in concentrates were significantly lower $(P<0.05)$ for the diet containing protected casein than for the other two diets (Table 1). Despite this, the proportion of DM from concentrates was maintained at approximately 0.67 of total DM intake. Concentrates supplied $0 \cdot 85-0.87$ of total $\mathrm{N}$ intake. 
Table 2. The effects on milk yield and composition and on concentrations of urea, glucose, $N E F A^{*}$, growth hormone, insulin, prolactin and thyroxine in blood of giving diets containing casein, protected casein or protected soya-bean meal to heifers in mid-lactation

(For details of diets see Table 1)

\begin{tabular}{|c|c|c|c|c|}
\hline Diet... & Casein & $\begin{array}{l}\text { Protected } \\
\text { casein }\end{array}$ & $\begin{array}{l}\text { Protected } \\
\text { soya }\end{array}$ & $\begin{array}{c}\text { SE of } \\
\text { difference }\end{array}$ \\
\hline \multicolumn{5}{|l|}{ Milk } \\
\hline Yield $(\mathrm{kg} / \mathrm{d})$ & $12 \cdot 9$ & $12 \cdot 3$ & $11 \cdot 9$ & 0.55 \\
\hline Fat $(\mathrm{g} / \mathrm{kg})$ & $33 \cdot 5$ & $36 \cdot 0$ & $33 \cdot 4$ & $1 \cdot 36$ \\
\hline Protein $(\mathrm{g} / \mathrm{kg})$ & $34 \cdot 4$ & $34 \cdot 0$ & $33 \cdot 1$ & 0.69 \\
\hline Lactose $(\mathrm{g} / \mathrm{kg})$ & $49 \cdot 0$ & $48 \cdot 8$ & $48 \cdot 9$ & 0.44 \\
\hline \multicolumn{5}{|l|}{ Blood } \\
\hline Urea $(\mathrm{mm} / 1)$ & $5 \cdot 12$ & $4 \cdot 32$ & $3 \cdot 88$ & 0.576 \\
\hline Glucose (mM/l) & $3 \cdot 41$ & 3.46 & $3 \cdot 45$ & 0.539 \\
\hline $\mathrm{NEFA}^{*}(\mu \mathrm{eq} / 1)$ & $189 \cdot 4$ & $217 \cdot 2$ & $214 \cdot 5$ & $16 \cdot 28$ \\
\hline Growth hormone $(\mathrm{ng} / \mathrm{ml})$ & $3 \cdot 01^{\mathrm{a}}$ & $5 \cdot 69^{b}$ & $5 \cdot 39^{\mathrm{b}}$ & 0.881 \\
\hline Insulin $(\mu \mathrm{U} / \mathrm{ml})$ & $16 \cdot 2$ & $21 \cdot 1$ & 12.5 & $4 \cdot 81$ \\
\hline Prolactin $(\mathrm{mg} / \mathrm{ml})$ & $15 \cdot 8$ & 14.0 & $13 \cdot 8$ & $3 \cdot 25$ \\
\hline Thyroxine (ng/ml) & $48 \cdot 4$ & $40 \cdot 3$ & $44 \cdot 9$ & 3.88 \\
\hline
\end{tabular}

a. b. Means which do not share a common superscript differ significantly $(P<0.05)$.

* Non-esterified fatty acids.

Milk yield, milk composition and the yield of milk components. Milk yield and the composition of milk were not affected significantly by treatments. Means for milk yield and the protein concentration in milk tended to be lowest with the protected soya-bean diet (Table 2). Milk fat yield for the protected soya-bean diet was significantly $(P<0.05)$ lower than for the protected casein diet.

Plasma urea, glucose and NEFA concentrations. Mean concentration of urea tended to be greatest, and that of NEFA least for the untreated casein diet but no differences were statistically significant (Table 2).

Plasma GH, insulin, prolactin and thyroxine concentrations. Plasma GH concentration was significantly higher $(P<0.05)$ for both forms of protected protein than for the untreated casein diet (Table 2). There were no other significant effects of treatment.

\section{DISCUSSION}

In this experiment, feeding formaldehyde-treated proteins to dairy heifers increased blood GH concentrations significantly in comparison with a diet containing untreated casein, but there was no effect of diet on yield of milk or on milk composition. The formaldehyde-treated proteins were used to increase protein supply to the abomasum in comparison with the untreated casein control (Hagemeister, 1977). The effects on blood GH concentration were consistent with our earlier observation that abomasal casein infusion increased blood $\mathrm{GH}$ concentration in goats (Oldham et al. 1978). Barry (1980) has also found that abomasal casein supplements increased blood GH concentration in lactating ewes.

Similar effects of high-protein meals on blood GH concentration have been seen in man (Knopf et al. 1966; Kasai et al. 1978) and in pigs (Atinmo et al. 1978).

Increasing protein supply to the intestine has not always resulted in increased blood $\mathrm{GH}$ concentration in ruminants. Gow et al. (1979) with goats, and Peel et al. (1981) with cows, found no increase in blood GH when a low protein basal ration was supplemented by casein infused into the abomasum. The reason for the difference between our observations and these others is not clear. It is possible that diet composition, especially where substantial 
amounts of starch are fed, may inhibit GH secretion (Fox et al. 1974; I. C. Hart \& J. D. Sutton, unpublished observations). The diets used by Gow et al. (1979) and by Peel et al. (1981) were likely to have had a high starch content - but so too did the diets used in our work. Alternatively, the discrepancy may have resulted from differences between experiments in the stage of lactation in which the experiments were conducted, or in basal levels of GH in the experimental animals (Bines \& Hart, 1982) or possibly in assay specificity (Cowie et al. 1980). Whatever the explanation it seems most appropriate to conclude that sometimes, but not always, changes in protein supply to the intestines in lactating ruminants will be associated with increased blood GH concentrations.

The effect of changes in protein supply on blood GH were independent of effects on milk secretion. The measurements were made in mid- to late-lactation when basal blood GH concentrations were expected to be low (Hart et al. 1978). This facilitated identification of responses in GH. By calculation, based on work by the Agricultural Research Council (1980), neither rumen degradable (RDP) nor undegraded dietary (UDP) protein supply was limiting for milk production, even for the untreated casein diet. The increases in $\mathrm{GH}$, resulting from an increased supply of amino acids to the intestine, were small in comparison with increases in $\mathrm{GH}$ known to elicit improvements in milk yield (Bines \& Hart, 1982). On these grounds the lack of a response in milk production to feeding formaldehyde-treated proteins was to be expected.

Previous work in which abomasal casein infusion has increased blood GH concentration (Oldham et al. 1978; Barry, 1980) has not allowed discrimination between a response in $\mathrm{GH}$ resulting directly from a change in protein supply to the gut, or an indirect result of a change in energy status resulting from increased milk secretion. The work reported here suggests a direct effect of protein supply on GH status independent of the effects on milk yield.

We are grateful to Mr D. J. Napper, Mr V. W. Johnson and their staff for help with the animal experimentation, to Mr R. A. D. Hora, Miss L. J. Watts, Mrs K. Danby and Mr E. Florence for analysis of samples and Mrs R. J. Fulford for statistical advice. We would like to thank L. E. Pritchitt \& Co. Ltd for the gifts of the protein ingredients used in the rations and for the considerable trouble they went to in preparing the protected proteins.

\section{REFERENCES}

Agricultural Research Council (1980). Nutrient Requirements of Ruminant Livestock. Farnham Royal: Commonwealth Agricultural Bureaux.

Atinmo, T., Baldijao, C., Houpt, K. A., Pond, W. G. \& Barnes, R. H. (1978). J. Anim. Sci. 4, 409.

Barry, T. N. (1980). N.Z. Jl. agric. Res. 23, 427.

Bines, J. A. \& Hart, I. C. (1982). J. Dairy Sci. (In the Press).

Cowie, A. T., Forsyth, I. A. \& Hart, I. C. (1980). Hormonal Control of Lactation, p. 230. Berlin: Springer-Verlag. Fox, D. G., Preston, R. L., Senft, B. \& Johnson, R. R. (1974). J. Anim. Sci. 38, 437.

Gordon, F. J. (1979). Anim. Prod. 28, 183.

Gow, C. B., Ranawana, S. S. E., Kellaway, R. C. \& McDowell, G. H. (1979). Br. J. Nutr. $41,371$.

Hagemeister, H. (1977). In Protein Nutrition and Metabolism p. 51, European Association for Animal Production publication no. 22. Pudoc, Wageningen: EAAP.

Hart, I. C., Bines, J. A., Morant, S. V. \& Ridley, J. L. (1978). J. Endocr. 77, 333.

Kasai, K., Kobayashi, M. \& Shimoda, S.-I. (1978). Metabolism 27, 201.

Knopf, R. F., Conn, J. W., Floyd, J. C., Fajans, S. S., Rull, J. A., Guntsche, E. M. \& Thiffault, C. A. (1966). Trans. Ass. Am. Physns 79, 312.

Marsh, W. H., Fingerhut, B. \& Miller, H. (1965). Clin. Chem., 11, 624.

Oldham, J. D. (1981). In Recent Advances in Animal Nutrition-1980, p. 33, [W. Haresign, editor]. London: Butterworths.

Oldham, J. D., Broster, W. H., Napper, D. J. \& Siviter, J. W. (1979). Br. J. Nutr. $42,149$.

Oldham, J. D., Hart, I. C. \& Bines, J. A. (1978). Proc. Nutr. Soc. 37, 9A.

Ørskov, E. R., Reid, G. W. \& McDonald, I. (1981). Br. J. Nutr. 45, 547. 
Peel, C. J., Fronk, T. J., Bauman, D. E. \& Gorewit, R. C. (1981). J. Dairy Sci., 64 (Suppl. 1), 124. Phipps, R. H., Weller, R. F., Smith, T. \& Fulford, R. J. (1981). J. agric. Sci., Camb. 96, 283.

Roffler, R. E., Satter, L. D., Hardie, A. R. \& Tyler, W. J. (1978). J. Dairy Sci. 61, 1422.

Wohlt, J. E. \& Clark, J. H. (1978). J. Dairy Sci. 61, 902. 